\title{
Role of red cell distribution width (RDW) in the detection of iron deficiency anaemia in pregnancy within the first 20 weeks of gestation
}

\author{
Sultana GS ${ }^{1}$, Haque $\mathrm{SA}^{2}$, Sultana $\mathrm{T}^{3}$, Rahman $\mathrm{Q}^{3}$, Ahmed $\mathrm{ANN}^{3}$. \\ ${ }^{I}$ Department of Clinical Pathology, Clinical Biochemistry and Haematology, BIRDEM, Dhaka, ${ }^{2}$ Department of \\ Thoracic Surgery, CMCH, Chittagong, ${ }^{3}$ Department of Clinical Pathology, BSMMU, Dhaka.
}

\begin{abstract}
Iron deficiency anemia is common problem during pregnancy. Red cell size variation (anisocytosis) is the earliest morphologic changes in iron deficiency anemia. Red cell distribution width is a quantitative measure of red cell size variation and it can give the idea of early iron deficiency before other test to become positive. 190 pregnant women were included in this study. Red cell distribution width was compared between iron deficient \& non-iron deficient pregnant women. Red cell distribution width also compared with $\mathrm{Hb}$ level, mean corpuscular volume, mean corpuscular hemoglobin, mean corpuscular hemoglobin concentration and peripheral blood film in prelatent iron deficiency, latent iron deficiency, mild and moderate iron deficiency anemia. Red cell distribution width had sensitivity $82.3 \%$ and specificity $97.4 \%$. Whereas $\mathrm{Hb}$ level, mean corpuscular volume, mean corpuscular hemoglobin, mean corpuscular hemoglobin concentration and peripheral blood film all had 56.6\%, $29.2 \%, 68.1 \%, 15 \%$ and $38.9 \%$ sensitivity but specificity was $90.9 \%, 98.7 \%, 83.1 \%, 96.1 \%$ and $98.7 \%$ in the detection of iron deficiency. Red cell distribution width appears to be a reliable and useful parameter for detection of iron deficiency during pregnancy.
\end{abstract}

\section{Introduction}

Anemia is a common problem during pregnancy and it affects $25 \%$ to $50 \%$ of the world population and $50 \%$ of pregnant women ${ }^{1}$. Iron deficiency anemia (IDA) is the predominant cause of anemia in pregnancy and early detection of anemia at low cost is essential. Red cell distribution width (RDW) is a new, routine parameter in fully automated hematology analyzer, which is included in complete blood count (CBC). RDW can give the idea of early changes in RBC, which is accompanied in iron deficiency anemia ${ }^{2}$. Women can be benefited by doing CBC including RDW for the diagnosis of early iron deficiency. Usually CBC is advised by the physician to all pregnant women for their antenatal checkup, which is less costly than iron profile. Physician can get the idea of early iron deficiency from RDW by advising $\mathrm{CBC}$ as a simple test. During pregnancy erythrocyte hypochromia and microcytosis are less prominent than non-pregnant, even in moderate iron deficiency $^{3}$. Red cell indices $(\mathrm{MCV}, \mathrm{MCH}$ and $\mathrm{MCHC}$ ) are mean value, which cannot express the small variation of red cells size, which is accompanied in early iron deficiency ${ }^{4}$. Whereas RDW can expresses the small variation of different population of red cell size 5 . In prelatent and latent iron deficiency, $\mathrm{Hb} \%$ and $\mathrm{MCV}$ are normal .In latent iron deficiency RDW would be expected to increase because a microcytic population of cells appears in the blood ${ }^{6}$. Again MCV is increased slightly in normal pregnancy, so may lead to misinterpretation of microcytosis. $\mathrm{MCH}$ and $\mathrm{MCHC}$ are reducing only when anemia is severe or established iron deficient women entered in pregnancy $^{7}$ As anisocytosis is less prominent in pregnancy and also in early iron deficiency anemia, Peripheral Blood Film (PBF) examination gives less information though it needs expert's opinion ${ }^{3,8}$. Iron profile is expensive and time consuming. During normal pregnancy serum iron, serum ferritin and percentage saturation falls and TIBC increases physiologically ${ }^{3,7,8}$. Though serum ferritin is gold standard for iron deficiency anemia but it is costly, may give misinterpretation due to physiological reduction and falsely elevated as an acute phase reactant ${ }^{3}$.

For this RDW is better guide then those tests in early iron deficiency. RDW is less explored in Bangladesh but Uddin et $\mathrm{al}^{9}$ showed the value of RDW as a diagnostic tool in IDA and various congenital haemoglobin disorders. The aim of this study is to determine the role of $\mathrm{RDW}$ in diagnosing early IDA in pregnancy.

\section{Materials and Methods}

This cross-sectional study was enrolled in dept of Clinical pathology and Obstetrics and Gynae outdoor, Bangabandhu Sheikh Mujib Medical University (BSMMU) from August 2008 to 2009. 
190 pregnant women within the first 20 weeks of gestation were included after scrutinizing inclusion and exclusion criteria. About $6 \mathrm{ml}$ blood was collected through an aseptic venepuncture from antecubital vein. $2 \mathrm{ml}$ blood was taken in EDTA tube for complete blood count including RDW and ESR. About $4 \mathrm{ml}$ blood was taken in a clean, dry plain test tube for serum iron profile. A drop of blood was taken on a glass slide for PBF. $\mathrm{Hb}$, $\mathrm{MCV}, \mathrm{MCH}, \mathrm{MCHC}, \mathrm{RDW}, \mathrm{PBF}$ and iron profile were done. Then all the pregnant women were categorized as Group I/iron deficient group (serum ferritin level $<12 \mathrm{ng} / \mathrm{ml}$ ) and Group II/non iron deficient group (serum ferritin 12 to $200 \mathrm{ng} / \mathrm{ml})^{10,11}$. Group II considered as control. Group I again categorized as pre-latent iron deficiency (Transferrin saturation $\geq 16 \%, \mathrm{Hb}$ normal), latent iron deficiency (Transferrin saturation <16\%, Hb normal), mild iron deficiency anaemia (Transferrin saturation $<16 \%, \mathrm{Hb} 10-10.9 \mathrm{gm} / \mathrm{dl})$, moderate iron deficiency anaemia (Transferrin saturation $<16 \%$, $\mathrm{Hb} 7-9.9 \mathrm{gm} / \mathrm{dl})^{6,12}$. Women with severe anaemia were excluded. RDW $>14.5 \%$ is considered as abnormal ${ }^{13 .}$ Serum ferritin level is the gold standard in the diagnosis of iron deficiency anemia in pregnancy ${ }^{14}$. Women with serum ferritin normal $(12-200 \mathrm{ng} / \mathrm{ml})$ or raised $(>200 \mathrm{ng} / \mathrm{ml})$, serum iron low $(<70 \mu \mathrm{g} / \mathrm{dl})$, TIBC normal $(250-435 \mu \mathrm{g} / \mathrm{dl})$ or low $(<250 \mu \mathrm{g} / \mathrm{dl})$ and ESR $>40 \mathrm{~mm} / \mathrm{hr}$ suggestive of anemia of chronic disorder were excluded ${ }^{15,16}$. Pregnant women with leucocytosis (TC $>17.1 \times 10^{9} / \mathrm{L}$ ) considered as acute infection was also excluded ${ }^{17}$. In IDA, RBC became microcytic hypochromic, poikilocyte, particularly tailed and elongated elliptical form were found ${ }^{6,18}$ (Figure $1 \&$ $2)$. Then the findings of laboratory investigation were recorded in a predetermined data collection sheet. Data were evaluated by standard statistical methods. Analysis was done by SPSS (Statistical package for social science) by applying appropriate formula. Sensitivity, specificity, accuracy, positive predictive values (PPV) and negative predictive values (NPV) of RDW, unpaired t test, Chi square test and ANOVA test were calculated in diagnosing iron deficiency anemia.

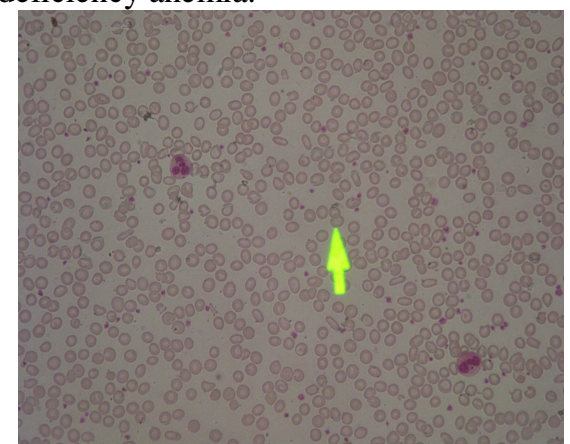

Fig. 1: $\mathrm{PBF}$ of case no 12 (Mild IDA) showing elongated and tear drop cells .Hb-10.3 gm/dl, MCV-78fl, RDW-18\% (X 400).

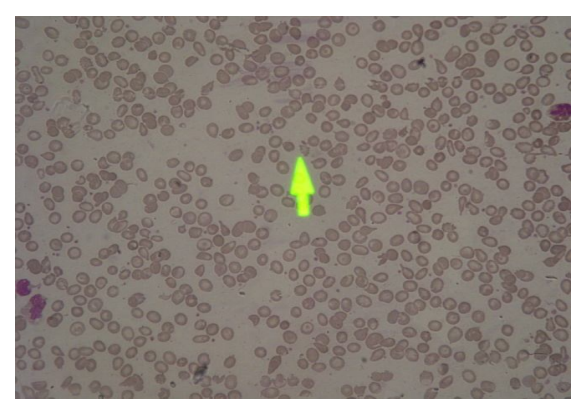

Fig. 2: PBF of case no 36 (Moderate IDA) showing some elongated cells .Hb-8gm/dl, RDW 19.5\%, MCV-64fl (X 400).

\section{Results}

RDW was compared between group I and group II. RDW also compared with $\mathrm{Hb}$ level, MCV, MCH, $\mathrm{MCHC}$ and $\mathrm{PBF}$ in prelatent iron deficiency, latent iron deficiency, mild and moderate IDA. RDW was statistically significantly $(\mathrm{P}<0.05)$ increased in iron deficient then non iron deficient. Again RDW was statistically significantly increased $(\mathrm{P}<0.05)$ than $\mathrm{Hb}$ level, MCV, MCH, MCHC and PBF in latent iron deficiency. In mild and moderate IDA, RDW was statistically significantly increased than MCV, MCHC and PBF (Figure 3\&4). Validity of RDW, $\mathrm{Hb}, \mathrm{MCV}, \mathrm{MCH}, \mathrm{MCHC}$ and PBF was done by calculating sensitivity, specificity, PPV, NPV and accuracy (Table I). In this study RDW had high sensitivity $82.3 \%$ than other test. But the specificity is slightly lower (97.4\%) than PBF \& MCV (98.7\%).

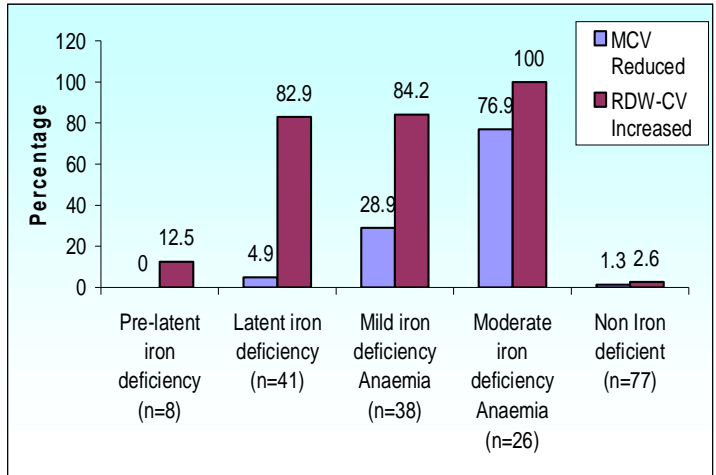

Fig. 3: Bar diagram showing difference of MCV and RDW-CV in the diagnosis of Iron deficiency of anaemia.

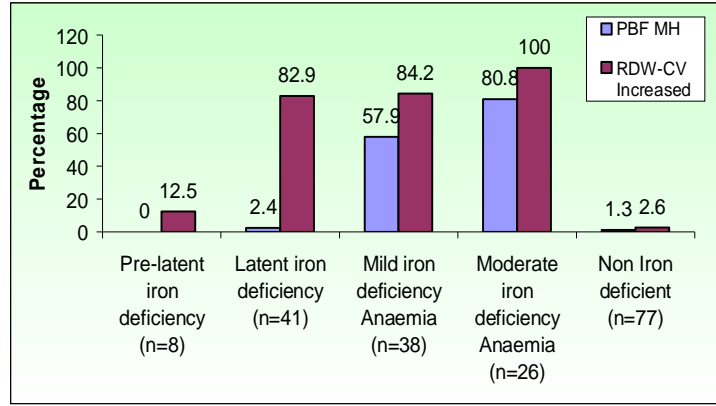

Fig. 4: Bar diagram showing difference of PBF and RDW in the diagnosis of Iron deficiency of anaemia. 
Table I: Sensitivity, specificity, accuracy, positive and negative predictive values of the $\mathrm{Hb}(\mathrm{gm} / \mathrm{dl}), \mathrm{MCV}(\mathrm{fl}), \mathrm{MCH}(\mathrm{pg}), \mathrm{MCHC}$ $(\mathrm{gm} / \mathrm{dl})$, RDW $(\%)$ and PBF in diagnosis of IDA $(\mathrm{n}=190)$.

\begin{tabular}{lcccccc}
\hline \multicolumn{1}{c}{ Validity test } & $\mathrm{Hb}$ & $\mathrm{MCV}$ & $\mathrm{MCH}$ & $\mathrm{MCHC}$ & $\mathrm{RDW}$ & $\mathrm{PBF}$ \\
\hline Sensitivity & 56.6 & 29.2 & 68.1 & 15.0 & 82.3 & 38.9 \\
Specificity & 90.9 & 98.7 & 83.1 & 96.1 & 97.4 & 98.7 \\
Accuracy & 70.5 & 57.4 & 74.2 & 47.9 & 88.4 & 63.2 \\
PPV & 90.1 & 97.1 & 85.6 & 85.0 & 97.9 & 97.8 \\
NPV & 58.8 & 48.7 & 64.0 & 43.5 & 78.9 & 52.4 \\
\hline
\end{tabular}

\section{Discussion}

During pregnancy women are prone to develop iron deficiency. Detection of latent iron deficiency is important but usually difficult to detect. Routine parameters are only useful in the detection of overt deficiency ${ }^{18}$. During pregnancy even mild and moderate iron deficiency may be misdiagnosed due to increase $\mathrm{MCV}$ and less findings found in $\mathrm{PBF}^{3}$. Due to physiologic alteration of plasma volume and red cell mass in pregnancy, $\mathrm{Hb}$ level are unreliable $\mathrm{e}^{3} \mathrm{Hb}$ determination is neither sensitive nor specific as a screening test for iron deficiency ${ }^{19}$. During latent stage few microcyte may appear in PBF thus RDW would expect to increase during this period ${ }^{6,20}$.

In this study $\mathrm{Hb}$ level was not reduced in prelatent, latent iron deficient pregnant women while RDW was increased in 1 pregnant women $(12.5 \%)$ and 34 women $(82.9 \%)$ of prelatent and latent ID. In mild and moderate IDA 38 women $(100 \%)$ and 26 women (100\%) had reduced $\mathrm{Hb}$ level but RDW was increased in 32 women (84.2\%) and 26 women $(100 \%)$. Therefore RDW was more significant than $\mathrm{Hb}$ level in latent ID when $\mathrm{Hb}$ level was normal. In mild and moderate IDA, RDW was increased progressively though $\mathrm{Hb}$ level was also reduced.

MCV was reduced in 20 women $(76.9 \%)$ with moderate IDA while RDW was increased in 34 $(82.9 \%), 32(84.2 \%)$ and $26(100 \%)$ women with latent ID, mild and moderate IDA. The difference of MCV and RDW level was statistically significant (p-0.001, 0.001 and 0.011) in latent, mild and moderate IDA, but not significant between prelatent and NID group (Figure 3).

In PBF study RBC morphology was seen in all grade of iron deficiency. Microcytosis and hypochromia was found in 21 pregnant women $(80.8 \%)$ out of 26 moderate IDA and 22 women $(57.9 \%)$ out of 38 in mild IDA. In latent iron deficiency only 1 women $(2.4 \%)$ had $\mathrm{MH}$. Whereas RDW was increased in $100 \%$ case of moderate IDA, $84.2 \%$ (32 cases) with mild IDA and $82.9 \%$
(34) case of latent ID. So the difference of PBF study and increased RDW was significant in latent, mild and moderate IDA ( $\mathrm{p}=0.001,0.011$ and 0.025$)$ (Figure 4).

In this study $\mathrm{Hb}$ level had sensitivity $56.6 \%$ and specificity $90.9 \%$ with accuracy $70.5 \%$ for iron deficiency. Casanova, Sammal and Macones ${ }^{1}$ also found low sensitivity (42.6\%) and high specificity $(86.2 \%)$ in IDA in pregnancy for $\mathrm{Hb}$ and classified $71.6 \%$ as iron deficient, but sensitivity and specificity was less than RDW, which was almost consistent with the present study.

In this study MCV had sensitivity $29.2 \%$ and specificity $98.7 \%$. Uchida ${ }^{12}$ found low sensitivity $(56.3 \%)$ and high specificity (91\%). Thompson et al. $^{21}$ also found low $(53 \%)$ sensitivity but high specificity (84\%). In this study MCH, MCHC also had low sensitivity $68.1 \%$ and $15.0 \%$ with specificity of $83.1 \%$ and $96.1 \%$.

Sensitivity of PBF in this study was low $38.9 \%$ but high specificity $98.7 \%$. Viswanath et al. ${ }^{4}$ also found low sensitivity $(48.31 \%)$ of PBF and high specificity $(90.9 \%)$. The result was almost similar with this study.

In this study RDW has the highest sensitivity $(82.3 \%)$ and specificity (97.4\%). Accuracy, PPV and NPV was found $88.4 \%, 97.9 \%$ and $78.9 \%$ respectively (Table I). Aulakh et $\mathrm{al}^{22}$ found almost same sensitivity $81.0 \%$ and NPV $72.4 \%$ but the specificity and PPV was low $53.4 \%$ and $63.0 \%$. vanZeben et $\mathrm{al}^{13}$ found sensitivity of RDW was 94\% and specificity 59\% and concluded that RDW was important than serum ferritin in infection, inflammation and tissue damage. Thompson et al. ${ }^{21}$ found sensitivity of RDW was $71 \%$. But Casenova, Sammal and Macones ${ }^{1}$ found RDW more than $15 \%$ has sensitivity and specificity $85.1 \%$ and $46.8 \%$ and correctly classified $72.3 \%$ women with iron deficiency.

This study has some limitation. Haemoglobin electrophoresis, serum Vit $\mathrm{B}_{12}$ or folate studies were not done to exclude hemoglobinopathies, early macrocytosis due to folic acid or Vit $\mathrm{B}_{12}$ deficiency where RDW may increase. Anaemia of chronic disorder also could not be excluded properly by appropriate investigation where serum ferritin may misinterpret.

Conclusion: Iron deficiency anemia in pregnancy produces various ill effects both for mother and foetus. For prevention of iron deficiency early diagnosis is essential. Iron deficiency and IDA without other complicating disease could be screened out early by increased RDW when $\mathrm{Hb}$, $\mathrm{RBC}$ indices and PBF were normal. RDW can give 
the idea of iron deficiency but for final diagnosis serum ferritin should be done. In a mass examination in tertiary hospital where automated analyzer is available, RDW is a simple, cost effective and non invasive technique that should facilitate the detection of early iron deficiency anemia before expert's opinion of PBF or iron profile test are available.

\section{Acknowledgement}

We acknowledge gratefully the pregnant mothers who in spite of their suffering helped us in this study and all the doctors and staff of clinical pathology and obstetrics department of BSMMU for their kind cooperation.

\section{References}

1. Casanova B, Sammel MD and Macones GA. Development of a clinical prediction rule for iron deficiency anaemia in pregnancy. American Journal of Obstetiics and Gynecology 2005; 193: 460-66.

2. Fairbanks V F and Beutler E. Iron Deficiency, In Beutler E, Lichtman M, Coller BS, Kipps TJ, Seligsohn $\mathrm{U}$, editors, Williams Hematology, $6^{\text {th }}$ edition, McGrawHill, North America, 2001; 447-57.

3. Cunningham FG, Gilstrap LC, Gant NF, Hauth JC, Wenstrom KD and Leveno KJ Maternal Adaptations to pregnancy, Williams obstetrics, $21^{\text {st }}$ edition, McGrawHill, New York, 2001; 167-70.

4. Viswanath D, Hegde R, Murthy V, Nagashree S and Shan R. Red cell distribution width in the diagnosis of iron deficiency anemia. Indian J Pediatr 2001; 68 (12): 1117-19.

5. Bain BJ and Bates I. Basic haematological techniques. In: Lewis SM, Bain BJ and Bates I, (eds). Dacie and Lewis Practical Haematolog. $9^{\text {th }}$ ed. London, Churchill livingstone Harcourt Publishers Ltd, 2001; 19-45.

6. Andrews NC, Disorder of Iron Metabolism and Heme Synthesis, in Greer JP, Foerster J, Lukens JN, Rodgers GM, Paraskevas F and Glader B (eds), Wintrobe's Clinical Hematology, $11^{\text {th }}$ edition, Lippincott Williums \& Wilkins, Philadelphia USA, 2004; 979-1002.

7. Rana S. Physiological changes and maternal adaptation to pregnancy, Obstetrics and perinatal care for developing countries. $5^{\text {th }}$ ed. Aabpara Islamabad, Pakistan, 2002; 172-86.

8. Duffy TP. Hematologic aspects of pregnancy, in Burrow GN and Duffy TP, editor. Medical complications during pregnancy. $5^{\text {th }}$ ed. W.B. Saunders, India, 2001; 79-82.

9. Uddin MM, Uddin MJ, Mahmud Z, Hassan SM M, Abedin AKM M, Rahman MM and Sultana SA. Value of Red Cell Distribution Width Index As A Diagnostic Tool In Iron Deficiency Anaemia And Various
Congenital Haemoglobin Disorders. Bangladesh J Pathol 2006; 21(2):14-18.

10. Glader B, Anaemia: General Considerations, in Greer JP, Foerster J, Lukens, JN, Rodgers, GM, Paraskevas, $\mathrm{F}$ and Glader, B (eds), Wintrobe's Clinical Hematology, $11^{\text {th }}$ edition, Lippincott Williums \& Wilkins, Philadelphia USA, 2004; 947-63.

11. Asif N, Hassan K, Mahmud S, Zaheer HA, Naseem L, Zafar $T$ and Shams R. Difference of serum ferritin levels in three trimester of pregnancy and their correlation with increasing gravidity. International Journal of Pathology 2007; 5(1): 26-30.

12. Uchida T. Change in red blood cell distribution width with iron deficiency. Clin lab Haemat 1989; 11: 11721.

13. van Zeben $\mathrm{D}$, Bieger $\mathrm{R}$, ven Wermeskerken RKA, Castel A, Hermans J. Evaluation of microcytosis using serum ferritin and red blood cell distribution width. Eur J Haematol 1990; 44: 105-8.

14. Brian S, Alper MD, Kimber R, Reddy A K. Using Ferritin Levels To Determine Iron-Deficiency Anemia in Pregnancy. The journal of family practice 2000; 49(9).

15. Novak RW. Red Blood Cell Distribution Width in Pediatric Microcytic Anaemias. Pediatrics 1987; 80: 251-54.

16. Lipschttz DA, Cook JD and Finch CA. A clinical evaluation of serum ferritin as an index of iron stores. N Eng J Med, 1974; 290: 1213-16.

17. Nissl J. Complete blood count. Merit Care Health system [cited 2009 September 25]: 1. Available from http// www.webmd.com/ a to z guides/complete blood count CBC, 2006.

18. Firkin F, Chesterman C, Penington D, Rush B, Hypochromic Anaemia: Iron Deficiency and Sideroblastic Anaemia, de Gruchy's, Clinical Haematology in Medical Practice, Blackwell Science, Oxford, 2006; 37-61.

19. Ferreira MU, Silva-Nunes $\mathrm{M}$, Bertolino $\mathrm{CN}$, Malafronte RS, Muniz PT and Cardoso MA .Anaemia and Iron Deficiency in Children, Adolescents, and Adults: A Community-Based Study in Rural Amazonia. American Journal of Public Health, 2007; 97(2):9-11.

20. Osborne PT, Burkett LL, Ryan GM and Lane M.An evaluation of red blood cell heterogeneity (increased red blood cell distribution on width) in iron deficiency of pregnancy. Am J Obstet Gynecol 1989; 160: 336-9.

21. Thompson WG, Meola T, Lipkin M, Freedman ML. Red cell distribution width, mean corpuscular volume and transferring saturation in the diagnosis of iron deficiency. Arch Intern Med 1988; 148: 2128-30.

22. Aulakh R, Sohi I, Singh T and Kakkar N. Red cell distribution width (RDW) in the diagnosis of iron deficiency with microcytic Hypochromic Anemia. Indian J Pediatr 2009; 76(3): 265-67. 